\title{
To what degree is palliative care integrated in guidelines and pathways for adult cancer patients in Europe: a systematic literature review
}

\author{
Karen Van Beek1, Naouma Siouta ${ }^{1 *}$, Nancy Preston², Jeroen Hasselaar ${ }^{3}$, Sean Hughes², Sheila Payne², \\ Lukas Radbruch ${ }^{4}$, Carlos Centeno ${ }^{5}$, Agnes Csikos $^{6}$, Eduardo Garralda ${ }^{5}$, Marlieke van der Eerden ${ }^{3}$, \\ Farina Hodiamont ${ }^{4}$, Ildiko Radvanyi ${ }^{6}$ and Johan Menten ${ }^{1}$
}

\begin{abstract}
Background: Palliative Care (PC) aims to improve the quality of life for patients with cancer and their families and its benefits have been demonstrated by several studies. The objective of this systematic review is to assess the integration of PC in the content of guidelines/pathways of adult cancer patients in Europe.

Methods: We included studies of adult patients with cancer published from 01/01/1995 and 31/12/2013 in Europe in six languages. We searched nine electronic databases, hand-searched six journals and also performed citation tracking. Studies were ranked using Emanuel's Integrated Palliative Care (IPC) criteria, a tool containing 11 domains to assess PC content in guidelines. Two reviewers screened the results and narrative synthesis has been employed.

Results: We identified a total of 28,277 potentially relevant articles from which 637 were eligible for full-text screening. The final review included 60 guidelines and 14 pathways. Eighty percent (80 \%) of the guidelines/pathways emphasize a holistic approach and $66 \%$ focus on PC interventions aimed at reducing suffering. Fifty seven percent (57 \%) did not discuss referral criteria for PC. Of all studies, five fulfilled at least 10/11 IPC criteria. Differences existed with regard to the referral criteria for bereavement care and the continuous adjustment of goals of care.

Conclusion: Overall, most of the identified guidelines/pathways highlighted the importance of the holistic approach of IPC. The studies that were found to fulfil at least 10/11 Emanuel's IPC criteria could serve as benchmarks of IPC.
\end{abstract}

Keywords: Delivery of Health Care, Integrated, Palliative care, Medical oncology, Systematic review, Guidelines, Pathways

\section{Background}

According to EUROSTAT [1], cancer constitutes the second most common cause of death in the European Union, which amounts for 29 and $23 \%$ of deaths for men and women, respectively. Moreover, these numbers are expected to increase as a result of the ageing of the population.

Palliative Care ( $\mathrm{PC}$ ) amounts to optimizing the quality of life for patients and their families facing problems associated with cancer, and other life-threatening disease more generally. In this framework, focus is placed on i)

\footnotetext{
* Correspondence: naouma.siouta@ppw.kuleuven.com

${ }^{1}$ Department of Radiation-Oncology and Palliative Medicine, University

Hospital Gasthuisberg, Leuven, Belgium

Full list of author information is available at the end of the article
}

the alleviation of symptoms, ii) the up-to-date communication of treatment goals and iii) the support for both patients and their families throughout the course of the illness trajectory. Importantly, the effectiveness of palliative care on the improvement of the quality of life of patients with advanced cancer has been corroborated by an ever-growing bulk of research evidence [2-6].

Several health-care authorities and medical associations including the World Health Organization (WHO), the European Society of Medical Oncology (ESMO), the American Society of Clinical Oncology (ASCO), The National Comprehensive Cancer Network (NCCN), The European Association for Palliative Care (EAPC) and Institute for Clinical Systems Improvement (ICSI) 
recommend the (early) integration of $\mathrm{PC}$ in the illness trajectory [2, 7-13]. However, available studies report that, at the end of life, patients with cancer usually receive suboptimal care [14], i.e. integration of PC remains limited. A critical examination of the status quo in Europe reveals that current European health-care delivery for patients with cancer is suboptimal both from the quality-of-care and from the financial perspective. In turn, this suboptimality is associated with a multitude of adverse effects, a non-exhausting list of which includes: i) patients unable to die at their place of preference [15-17], ii) large discrepancies in treatment trajectories and (non)treatment strategies in those with advanced cancer, indicating limited consensus on optimal treatment pathways $[18,19]$ and iii) considerable risks for overburdening of informal caregivers, translating into an imbalance in care networks surrounding the patient [20-23].

Central to the successful development and implementation of integrated PC strategies are the concepts of guidelines and pathways. Guidelines are systematically developed statements to assist practitioners and patient decisions about appropriate health care for specific clinical circumstances. They can be national, international or local. As such, they are often used as a means to reduce variations in treatments within health-care systems, to develop hospital-tailored protocols, to educate students, to assist insurers etc., [24-26]. On the other hand, a care pathway is defined as a complex intervention for the mutual decision making and organisation of care processes for a well-defined group of patients during a well-defined period. A pathway may use guidelines to provide clinical care.

The objective of the present study is to identify existing guidelines and pathways of integrated PC for people with cancer in the European Union and evaluate their completeness of content regarding their level of PC integration by conducting a systematic review of the available literature.

\section{Methods}

Despite the fact that there is a growing awareness of integrated palliative care (IPC) a unanimously agreed definition for it does not exist. For the scopes of this study, the InSup-C experts developed a consensus based definition that reads:

"Integrated palliative care involves bringing together administrative, organisational, clinical and service aspects in order to realise continuity of care between all actors involved in the care network of patients receiving palliative care. It aims to achieve quality of life and a well-supported dying process for the patient and the family in collaboration with all the care givers (paid and unpaid)".

\section{Search strategy}

The following databases were searched electronically: The Cochrane Central Register of Controlled Trials (CENTRAL), PubMed, EMBASE, CINAHL, AMED, British Nursing index (BNI), Web of Science, National Guidelines Clearinghouse and NHS Evidence. The search in the databases was performed using judiciously chosen keywords and search terms as well as their permutations/combinations. The basic search terms and keywords that were used in the electronic databases are presented in Table 1.

Additionally, the following journals were handsearched: BMJ Supportive \& Palliative care, European Journal of Palliative Care, Journal of Pain and Symptom Management, Palliative Medicine, Medicina Paliativa and the references from the included guidelines/ pathways.

The grey literature search consisted of two parts. For the first part, named individuals within national scientific medical organizations, were contacted with the aim of gathering information on guidelines and pathways. Examples of professional organizations included national bodies for oncology and palliative care development. The second part consisted of a grey literature search involving an electronic search in Google. For this search, the search strategy was translated in the languages of the authors participating in this study.

\section{Selection criteria}

As mentioned in the introduction, this study is performed in the context of the InSup-C research project. For this reason, in compliance with the project's objectives this review is geographically limited in Europe. Further, the following inclusion criteria were used:

1. Guidelines and pathways for adult patients.

2. Guidelines and pathways for cancer (latest possible versions).

3. European guidelines and pathways.

Table 1 Search terms used for the database search (hospices OR supportive care OR supportive care* OR end of life care* OR palliative* OR palliative care [MeSH Terms] OR hospice* OR terminal care* OR coordinated care* OR integrated care* OR transmural care* OR progressive patient care*) AND ("end stage disease" OR end stage disease* OR dying OR death [MeSH Terms] OR Chronic disease [MeSH Terms] OR Chronic disease* OR terminally ill* OR terminally ill [MeSH Terms] OR cancer) AND (care pathway* OR care pathway OR pathway* OR patient transfer* OR patient transfer OR patient care team* OR managed care program* OR continuity of patient care OR patient care management OR patient care plan* OR patient care planning OR illness trajectory OR "advance care planning" OR advance care planning OR delivery of health care OR models of care OR model of care OR model organizational OR models organizational OR organizational model* OR guideline*) NOT ((birth) OR child) OR pediatrics)) NOT ((animals[mh] NOT

humans[mh])) Filters: Publication date from 1995/01/01 to 2013/12/31 
4. Guidelines and pathways published from 01-01-1995 to 31-12-2013 (with the start date based on the publication of the Calman-Hine report which constitutes the first national cancer plan in Europe [27]).

5. Languages: English, French, German, Dutch, Hungarian and Spanish (the languages of the authors)

To distinguish between studies focusing on PC from those focusing on IPC, a sixth eligibility criterion is needed. In the present study, we measure the completeness of the IPC content of the guidelines/pathways via a tool based on Emanuel's IPC criteria. This is a template designed by the American Hospice Foundation Guidelines Committee to provide a practical approach for guideline writers and others to integrate $\mathrm{PC}$ into disease management and care services whenever it is relevant [28]. These criteria are described in Table 2. For the needs of the present study, and following a consensus in the InSup-C consortium, a guideline/pathway is considered to focus on IPC if it fulfils at least two out of the 11 criteria. Therefore, guidelines/pathways that fulfilled at most one criterion were labelled as non-eligible.

It is important to note that, to the best of our knowledge, Emanuel's criteria constitute the only tool that evaluates the content of the guidelines/pathways regarding the level of PC integration. Consequently, even though this tool has not been empirically validated, it has been chosen as the best choice.

\section{Selection procedure}

In the first phase, the first two authors (KVB and NS) screened all the English search results based on their titles and their abstract. Non English texts were screened and translated by two native speaker researchers. Then the full texts of the guidelines/pathways selected by both authors were sourced and they were reviewed based on the aforementioned inclusion/exclusion criteria.

Table 2 Integrated Palliative Care (IPC) Criteria

\footnotetext{
1. Discussion of illness limitations and prognosis.

2. Recommendations for conducting a whole patient assessment including the patient's physical, social, psychological, and spiritual issues, their family and community setting.

3. Recommendations for when to make these assessments (e.g. At baseline and periodically thereafter).

4. Recommendations on when palliative care should be integrated.

5. Assessment of the patient's goals for care.

6. Continuous goal adjustment as the illness and the person's disease progresses.

7. Palliative care interventions to reduce suffering as needed.

8. Advance care planning.

9. Recommendation of involving a palliative care team (interdisciplinary team, palliative care consultation or other palliative care services).

10. Recommendations on care during the last hours of living.

11. Recommendations on grief and bereavement care.
}

Discrepancies were resolved by consensus or they were extensively discussed in consecutive project meetings.

\section{Data extraction}

Data were extracted from guidelines/pathways meeting the inclusion criteria using a data extraction form. This form was based on the extraction form described in Hawker et al. [29], but it was adjusted accordingly to the purposes of our study after consensus in the project meetings. For each included paper, data extraction was carried out by the two first authors independently for the English results and by two native speaker researchers for the non-English ones. Upon the completion of the process, the two reviewers cross-checked their results and reached consensus in case of discrepancies.

\section{Evidence quality assessment}

In order to assess the quality of the evidence of the guideline/pathways, we employed the following methodology. Guidelines/pathways that were based on both systematic reviews and consensus methods (e.g. nominal group techniques, Delphi rounds, expert consultations) or those developed by following the NICE protocol [30] were considered high quality evidence; guidelines/pathways based on systematic review only or based on other types of well referenced evidence were considered medium quality whereas those based on consensus methods only were considered low quality. Finally, guidelines/pathways whose basis was unclear (e.g. apparently evidence based but failing to clarify how this was obtained) were considered of very low quality. This quality assessment guide was agreed upon during consensus between the authors.

\section{Data synthesis}

The included studies are characterized by a substantial heterogeneity. For this reason, a narrative synthesis has been considered appropriate and results have tabulated in easily accessible tables (Tables 3 and 4).

\section{Results}

We identified a total of 28,277 potentially relevant documents/records, of which 24,794 were excluded based on their titles or abstracts. No additional articles were identified through consultation with experts and national health organizations. An additional 3021 relevant papers were identified from the hand-searched journals, citation tracking and the grey literature, of which 2905 were not eligible for full text screening. Full-text review was performed on the remaining 521 articles from the electronic database search and 116 articles from the other sources mentioned above. The final review included 74 papers of which 60 were guidelines [31-90] and 14 pathways [91-104]. The characteristics of these 
Table $\mathbf{3}$ Characteristics of included Cancer Guidelines

\begin{tabular}{l} 
Cancer guidelines \\
\hline Title/Country/Year \\
Interdisciplinary guideline of quality \\
for early detection, diagnosis and \\
treatment of different stages of \\
prostate cancer/Germany/2011. [31] \\
Practice guideline for palliative care/
\end{tabular}

Practice guideline for palliative care/ Germany/2009. [32]

Interdisciplinary guidelines for the diagnosis, treatment and follow-up of breast cancer/Germany/2012. [33]

Guideline: Prevention, Diagnosis, Therapy, and Follow-up of Lung Cancer. (Germany, 2010) [34]

Malignant melanoma S3-guideline: Diagnosis, treatment and aftercare of melanoma. (Germany, 2013) [35]

Cancer pain. (Germany, 2007) [36]

Directive of the Federal Joint Committee on the Regulation of specialized outpatient palliative care. (Germany, 2007). [37]

National Practice Guideline pancreatic cancer. (Belgium, 2009) [38]

Small cell and non- small cell lung cancer: diagnosis, treatment and follow-up. (Belgium, 2013) [39]

National Practice Guideline of oesophageal and stomach cancer UPDATE. (Belgium, 2012) [40]

Palliative Care Unit: Standards and Recommendations. (Spain, 2009) [41]

Clinical Practice Guidelines on Palliative Care. (Spain, 2008) [42]

Palliative Care Guideline. (Spain, no date available) [43]

Palliative Care Guideline in the Community of Madrid.

(Spain, 2008) [44]

Clinical recommendations guideline: colorectal cancer. (Spain, 2006). [45]

Guideline Care in the dying phase. (The Netherlands, 2010) [46] inpatient/ outpatient

inpatient/ outpatient

inpatient/ outpatient

inpatient/ outpatient

outpatient

inpatient

inpatient

inpatient

inpatient/ outpatient

inpatient/ outpatient

inpatient/ outpatient

inpatient/ outpatient

inpatient/ outpatient
Emanuel's criteria (EMC)

Quality of

evidence

7 EMC: Discussion of illness limitations and prognosis,

Holistic assessments, Timing of PC introduction, Patient's

High

goals, Suffering reduction, ACP, Involvement of PC team.

9 EMC: Holistic assessments, Timing of PC introduction, Patient's goals, Continuous goal adjustment, Suffering reduction, ACP, Involvement of PC team, Last hours of living care, Grief and bereavement care.

9 EMC: Discussion of illness limitations and prognosis, Holistic assessments, Timing of holistic assessments, Timing of PC introduction, Patient's goals, Continuous goal adjustment, Suffering reduction, Involvement of PC team, Last hours of living care.

9 EMC: Discussion of illness limitations and prognosis, Holistic assessments, Timing of PC introduction, Patient's goals, Continuous goal adjustment, Suffering reduction, ACP, Involvement of PC team, Last hours of living care.

7 EMC: Discussion of illness limitations and prognosis, Holistic assessments, Timing of holistic assessments, Timing of PC introduction, Suffering reduction, ACP, Involvement of PC team.

3 EMC: Holistic assessments, Timing of holistic assessments, Continuous goal adjustment.

6 EMC: Holistic assessments, Patient's goals, Suffering reduction, ACP, Involvement of PC team, Last hours of living care.

3 EMC: Holistic assessments, Timing of PC introduction, Involvement of PC team

2 EMC: Patient's goals, ACP.

4 EMC: Holistic assessments, Timing of PC introduction, Suffering reduction, Involvement of PC team.

8 EMC: Discussion of illness limitations and prognosis, Holistic assessments, Timing of PC introduction, Patient's goals, Suffering reduction, ACP, Involvement of PC team, Grief and bereavement care.

10 EMC: Discussion of illness limitations and prognosis, Holistic assessments, Timing of PC introduction, Patient's goals, Continuous goal adjustment, Suffering reduction, $\mathrm{ACP}$, Involvement of PC team, Last hours of living care, Grief and bereavement care.

3 EMC: Involvement of PC team, Last hours of living care, Grief and bereavement care.

5 EMC: Discussion of illness limitations and prognosis, Holistic assessments, Timing of PC introduction, Suffering reduction, Last hours of living care.

4 EMC: Holistic assessments, Timing of PC introduction, Continuous goal adjustment, Grief and bereavement care.

8 EMC: Discussion of illness limitations and prognosis, Holistic assessments, Timing of PC introduction, Patient's goals, Suffering reduction, ACP, Last hours of living care, Grief and bereavement care.
High

High

High

Low

High

High

High

Very low

Very low

Very low

High

Low 
Table 3 Characteristics of included Cancer Guidelines (Continued)

\begin{tabular}{ll}
\hline $\begin{array}{l}\text { Guideline Leptomeningeal metastases. } \\
\text { (The Netherlands, 2010) [47] }\end{array}$ & $\begin{array}{l}\text { inpatient/ } \\
\text { outpatient }\end{array}$ \\
$\begin{array}{l}\text { Guideline Oncologic Rehabilitation. } \\
\text { (The Netherlands, 2011) [48] }\end{array}$ & $\begin{array}{l}\text { inpatient/ } \\
\text { outpatient }\end{array}$ \\
$\begin{array}{l}\text { Guideline NSCLC. } \\
\text { (The Netherlands, 2011). [49] }\end{array}$ & $\begin{array}{l}\text { inpatient/ } \\
\text { outpatient }\end{array}$ \\
$\begin{array}{l}\text { Guideline Melanoma. } \\
\text { (The Netherlands, 2013) [50] }\end{array}$ & inpatient/ \\
Guideline Oesophagus carcinoma. & outpatient \\
(The Netherlands, 2010) [51] & inpatient/ \\
& outpatient
\end{tabular}

Guideline Pancreas carcinoma.

(The Netherlands, 2011) [52]

Guideline cervix carcinoma.

(The Netherlands, 2012) [53]

Guideline Endometrial carcinoma.

(The Netherlands, 2011) [54]

Guideline Sarcoma carcino-sarcoma uterus. (The Netherlands, 2010) [55]

Guideline Hypo-pharynx carcinoma.

(The Netherlands, 2010) [56]

Guideline Larynx carcinoma.

(The Netherlands, 2010) [57]

Guideline Mouth and oropharynx carcinoma. (The Netherlands, 2004) [58]

Guideline Breast cancer.

(The Netherlands, no date available) [59]

Guideline Prostate carcinoma.

(The Netherlands, 2007) [60]

Professional Guideline (Directive) of the Hungarian Public Healthcare.

(Hungary, 2013) [61]

Recommendations for the development of an integrative and complex palliative care in Hungary. (Hungary, 2013) [62]

Guidance on Cancer Services: Improving Supportive and Palliative Care for Adults with Cancer. (UK, 2004) [63]

Making good care better: National practice statements for general palliative care in adult care homes in Scotland.

(UK-Scotland, 2006) [64]

The diagnosis and treatment of lung Cancer-updated. (UK, 2011) [65] inpatient/

outpatient

inpatient/

outpatient

inpatient/

outpatient

inpatient/

outpatient

inpatient/

outpatient

inpatient/ outpatient

inpatient/ outpatient

inpatient/ outpatient

inpatient/ outpatient

inpatient

inpatient/ outpatient

inpatient/ outpatient

outpatient

inpatient

4 EMC: Discussion of illness limitations and prognosis,

Holistic assessments, Timing of PC introduction, Suffering reduction.

6 EMC: Holistic assessments, Timing of holistic assessments, Timing of PC introduction, Patient's goals, Continuous goal adjustment, Suffering reduction.

5 EMC: Discussion of illness limitations and prognosis, Holistic assessments, Timing of holistic assessments, Patient's goals, Suffering reduction.

3 EMC: Discussion of illness limitations and prognosis, Timing of PC introduction, Suffering reduction.

8 EMC: Discussion of illness limitations and prognosis, Holistic assessments, Timing of holistic assessments, Timing of PC introduction, Patient's goals, Continuous goal adjustment, Suffering reduction, ACP.

3 EMC: Discussion of illness limitations and prognosis, Patient's goals, Suffering reduction.

4 EMC: Discussion of illness limitations and prognosis, Holistic assessments, Suffering reduction, ACP, Involvement of PC team.

2 EMC: Discussion of illness limitations and prognosis, Involvement of PC team.

2 EMC: Holistic assessments, Involvement of PC team.

5 EMC: Discussion of illness limitations and prognosis, Holistic assessments, Timing of holistic assessments, Timing of PC introduction, Suffering reduction.

5 EMC: Discussion of illness limitations and prognosis, Holistic assessments, Timing of holistic assessments, Timing of PC introduction, Suffering reduction.

5 EMC: Discussion of illness limitations and prognosis, Holistic assessments, Timing of holistic assessments, Timing of PC introduction, Suffering reduction.

4 EMC: Discussion of illness limitations and prognosis, Holistic assessments, Timing of holistic assessments, Suffering reduction.

3 EMC: Discussion of illness limitations and prognosis, Holistic assessments, Patient's goals.

10 EMC: Discussion of illness limitations and prognosis, Holistic assessments, Timing of holistic assessments, Patient's goals, Continuous goal adjustment, Suffering reduction, ACP, Involvement of PC team, Last hours of living care, Grief and bereavement care.

8 EMC: Discussion of illness limitations and prognosis, Timing of holistic assessments, Timing of PC introduction, Patient's goals, Continuous goal adjustment, Suffering reduction, ACP, Grief and bereavement care.

9 EMC: Discussion of illness limitations and prognosis, Holistic assessments, Timing of holistic assessments, Patient's goals, Suffering reduction, ACP, Involvement of PC team, Last hours of living care, Grief and bereavement care.

8 EMC: Holistic assessments, Patient's goals, Continuous goal adjustment, Suffering reduction, ACP, Involvement of PC team, Last hours of living care, Grief and bereavement care.

4 EMC: Discussion of illness limitations and prognosis, Holistic assessments, Timing of holistic assessments, Suffering reduction.
High

Medium

High

High

High

High

High

High

Low

High

High

High

High

High

Medium

High

High

Low 
Table 3 Characteristics of included Cancer Guidelines (Continued)

Head and Neck Cancer: Multidisciplinary

Management Guidelines. (UK, 2011) [66]

Guidelines for supportive care in multiple myeloma 2011. (UK, 2011) [67]

The NICE Guidance on Supportive and Palliative Care Implications for Oncology Teams. (UK, 2004) [68]

Metastatic malignant disease of unknown primary origin. Diagnosis and management of metastatic malignant disease of unknown primary origin. (UK, 2010) [69]

Palliative and End of Life Care Indicators. (UK-Scotland, 2013) [70]

Core competencies in palliative care: an EAPC White Paper on palliative care education. Parts 1 \& 2. (UK, 2013) [71]

Dying well at home: the case for integrated working: Guide 48. (UK, 2013) [72]

RCGP commissioning guidance in end of life care : guidance for GPs, clinical commissioning group advisers. (UK, 2013) [73]

Optimising the role and value of the interdisciplinary team: providing person centred end of life care. (UK, 2013) [74]

Strategy for adult palliative and end of life care services. (UK, 2013) [75]

End of Life Care Strategy: Fourth Annual Report. (UK, 2012) [76]

Matters of life and death: helping people to live well until they die. General practice guidance for implementing the RCGP/RCN end of life care patient charter. (UK, 2012) [77]

End of life care for adults in the Emergency Department. (UK, 2012) [78]

CMG42 End of life care for adults. (UK, 2011) [79]

Commissioning guidance for specialist palliative care : helping to deliver commissioning objectives. (UK, 2012) [80]

Commissioning person centred end of life care. (UK, 2012) [81]

Quality standard for end of life care for adults. (UK, 2011) [82] inpatient/

7 EMC: Discussion of illness limitations and prognosis,

Holistic assessments, Patient's goals, Continuous goal adjustment, Suffering reduction, Involvement of PC team, Last hours of living care.

inpatient

4 EMC: Holistic assessments, Timing of holistic assessments, Suffering reduction, ACP, Last hours of living care.

inpatient 5 EMC: Holistic assessments, Patient's goals, Suffering reduction, Involvement of PC team, Grief and bereavement care.

inpatient

3 EMC: Discussion of illness limitations and prognosis, Holistic assessments, Continuous goal adjustment.

inpatient/ outpatient

inpatient/ outpatient

inpatient/outpatient

inpatient/outpatient

3 EMC: Discussion of illness limitations and prognosis, Patient's goals, ACP.

8 EMC: Discussion of illness limitations and prognosis, Holistic assessments, Timing of holistic assessments, Patient's goals, Continuous goal adjustment, ACP, Involvement of PC team, Grief and bereavement care.

. Holistic assessments, Patient's goals, Suffering reduction, ACP, Involvement of PC team, Last hours of living care, Grief and bereavement care.

7 EMC: Discussion of illness limitations and prognosis, Holistic assessments, Patient's goals, Continuous goal adjustment, Involvement of PC team, Last hours of living care, Grief and bereavement care.

inpatient/outpatient

9 EMC: Discussion of illness limitations and prognosis, Holistic assessments, Timing of holistic assessments, Patient's goals, Continuous goal adjustment, ACP, Involvement of PC team, Last hours of living care, Grief and bereavement care.

inpatient/outpatient

8 EMC: Discussion of illness limitations and prognosis, Holistic assessments, Patient's goals, Continuous goal adjustment, Suffering reduction, Involvement of PC team, Last hours of living care, Grief and bereavement care.

inpatient/outpatient

3 EMC: ACP, Last hours of living care, Grief and bereavement care.

inpatient/outpatient 11 EMC: Discussion of illness limitations and prognosis, Holistic assessments, Timing of holistic assessments, Timing of PC introduction, Patient's goals, Continuous goal adjustment, Suffering reduction, ACP, Involvement of PC team, Last hours of living care, Grief and bereavement care.

inpatient

4 EMC: Discussion of illness limitations and prognosis, Timing of PC introduction, ACP, Involvement of PC team.

inpatient/outpatient 11 EMC: Discussion of illness limitations and prognosis, Holistic assessments, Timing of holistic assessments, Timing of PC introduction, Patient's goals, Continuous goal adjustment, Suffering reduction, ACP, Involvement of PC team, Last hours of living care, Grief and bereavement care.

inpatient/outpatient 6 EMC: Discussion of illness limitations and prognosis, Holistic assessments, Timing of PC introduction, Patient's goals, ACP, Involvement of PC team.

inpatient/outpatient - 2 EMC: ACP, Involvement of PC team.

inpatient/outpatient

8 EMC: Holistic assessments, Timing of holistic assessments, Patient's goals, Continuous goal adjustment, ACP, Involvement of PC team, Last hours of living care, Grief and bereavement care.

inpatient/outpatient 3 EMC: Holistic assessments, Timing of holistic assessments, Involvement of PC team.
High

High

High

High

Low

Low

Low

Low

Low

Low 
Table 3 Characteristics of included Cancer Guidelines (Continued)

\begin{tabular}{|c|c|c|c|}
\hline $\begin{array}{l}\text { Review of palliative care services in } \\
\text { Scotland. (UK-Scotland, 2008) [84] }\end{array}$ & inpatient/outpatient & $\begin{array}{l}4 \text { EMC: Holistic assessments, Patient's goals, ACP, } \\
\text { Involvement of PC team. }\end{array}$ & High \\
\hline $\begin{array}{l}\text { Living and Dying Well: A national action } \\
\text { plan for palliative and end of life care in } \\
\text { Scotland. (UK-Scotland, 2008) [85] }\end{array}$ & $\begin{array}{l}\text { inpatient/ } \\
\text { outpatient }\end{array}$ & $\begin{array}{l}8 \text { EMC: Discussion of illness limitations and prognosis, } \\
\text { Holistic assessments, Timing of holistic assessments, } \\
\text { Timing of PC introduction, Patient's goals, Suffering } \\
\text { reduction, ACP, Involvement of PC team. }\end{array}$ & Low \\
\hline $\begin{array}{l}\text { Metastatic spinal cord compression: } \\
\text { Diagnosis and management of patients } \\
\text { at risk of or with metastatic spinal cord } \\
\text { compression. (UK, 2008) [86] }\end{array}$ & $\begin{array}{l}\text { inpatient/ } \\
\text { outpatient }\end{array}$ & 2 EMC: Holistic assessments, Involvement of PC team. & High \\
\hline End of life care. (UK, 2008) [87] & $\begin{array}{l}\text { inpatient/ } \\
\text { outpatient }\end{array}$ & $\begin{array}{l}5 \text { EMC: Holistic assessments, Patient's goals, ACP, } \\
\text { Last hours of living care, Grief and bereavement care. }\end{array}$ & Medium \\
\hline $\begin{array}{l}\text { National Care Standards: Hospice } \\
\text { Care. (UK, 2005) [88] }\end{array}$ & $\begin{array}{l}\text { inpatient/ } \\
\text { outpatient }\end{array}$ & $\begin{array}{l}2 \text { EMC: Last hours of living care, Grief and bereavement } \\
\text { care. }\end{array}$ & Low \\
\hline $\begin{array}{l}\text { Clinical Standards: Specialist palliative } \\
\text { care. (UK, 2002) [89] }\end{array}$ & inpatient & $\begin{array}{l}7 \text { EMC: Discussion of illness limitations and prognosis, } \\
\text { Holistic assessments, Patient's goals, Continuous goal } \\
\text { adjustment, ACP, Involvement of PC team, Grief and } \\
\text { bereavement care. }\end{array}$ & Low \\
\hline $\begin{array}{l}\text { Improving outcomes in gynaecological } \\
\text { cancer: The Manual. (UK, 1999) [90] }\end{array}$ & inpatient/outpatient & 2 EMC: Holistic assessments, Suffering reduction. & High \\
\hline
\end{tabular}

studies can be found in Tables 3 and 4. A flow diagram of the selection procedure and results (using the PRISMA tool [105]) is shown in Fig. 1.

Of the 60 guidelines included in the final review, 28 guidelines originated from the UK, seven from Germany, three from Belgium, five from Spain, 15 from the Netherlands and two from Hungary. Additionally, four pathways originated from the UK and Spain, three from the Netherlands and one from Belgium, Germany and Hungary. Twenty eight guidelines and five pathways can be considered as cancer specific (e.g. breast cancer guidelines, lung cancer guidelines, etc.). Four guidelines deal with general oncology, 11 guidelines and three pathways with the dying phase for patients with cancer and chronic disease, 16 guidelines and six pathways with $\mathrm{PC}$ in general and one guideline is about general health care. It is important to note here, that the guidelines/ pathways focused on general PC and general health care are not irrelevant to the scopes of this systematic review because they are concerned with patients with cancer. In this respect, these guidelines/pathways fulfil the inclusion criterion on the type of the disease and as such they are included in the study. Further information on these guidelines and pathways is presented in Tables 3 and 4 .

Looking at the results of the quality assessment of the evidence, we have to stress that the assessment employed in the present systematic review does not assess the quality of the implementation of the included guidelines/pathways. Rather, it provides a means of evaluating the principles upon which they have been developed. Very low quality guidelines/pathways corresponded to only $11 \%$ of the total number. Guidelines/ pathways with low quality were $27 \%$. Only a handful of studies (7 \%) were categorised as medium quality. Finally, the majority of the included guidelines/pathways (55\%) were classified as of high quality evidence.

The assessment of the palliative care content of the guidelines/pathways via the IPC criteria revealed the following information. Nearly $80 \%$ of the studies placed particular emphasis on the holistic approach, namely the assessment of the patient's physical, psychological, social and spiritual issues, although only half of these recommendations (37\%) specified the exact timing on when these holistic assessments should take place. Of all guidelines/pathways, $47 \%$ reported on the timing at which palliative care should be integrated. An additional $66 \%$ of the guidelines/pathways focused on palliative care interventions aimed at reducing suffering. Interestingly, $75 \%$ of the included guidelines/pathways referred to both an inpatient and an outpatient PC setting, as opposed to 16 and $8 \%$ that referred solely to an inpatient and an outpatient PC setting, respectively. Moreover, $55 \%$ of the guidelines/pathways explicitly put emphasis on discussion of illness limitations and prognosis and $55 \%$ elaborated on the assessment of the patient's goals for care.

Just less than half of the included guidelines/pathways paid attention to aspects of advance care planning (46\%) and grief and bereavement care (40\%). Furthermore recommendations for continuous goal adjustment (38\%), recommendations of care during the last hours of life (47\%) and recommendations for the involvement of a palliative care team (58\%), were mixed.

Guidelines and pathways that achieved a high score using the IPC criteria were judged to comprehensively address the core components of IPC. Two guidelines 
Table 4 Characteristics of included Cancer Pathways

Cancer pathways

Title/Country/Year

Palliative Medicine: Essays - Reports -

Discussion Posts - Comments: Liverpool

Care Pathway Practical assistance.

(Germany, 2008) [91]

Practice and opportunities of the Hungarian hospice care provided at home. (Hungary, 2013) [92]

Palliative care pathway in General Practice. (Belgium, 2012) [93]

outpatient

Setting

Inpatient/outpatient

Integrated Oncological Pathways: prostate carcinoma. (The Nederlands, 2010) [94]

Integrated Oncological Pathways: colon-rectum carcinoma. (The Nederlands, 2010) [94]

Flow chart glioblastoma.

(The Nederlands, 2012) [96]

Manual for the management of patients in palliative care in outpatient ER.

(Spain, 2011) [97]

Home care program in primary care.

(Spain, 2004) [98]

Integrated care process of Palliative Care. (Spain, 2007) [99]

Palliative care in the oncologic patient. Documents for integrated care processes related to cancer management.

(Spain, 2005) [100]

Care pathway for the last days of life. (UK-Wales, 2004) [101]

The route to success in end of life care: achieving quality for social work. (UK, 2012) [102]

Quality in melanoma care: a best practice pathway. (UK, 2012) [103]

Derbyshire End of Life Care Guidance: a pathway for supporting people in the last year of life. (UK, 2010) [104]

inpatient/outpatient

outpatient

outpatient

inpatient

Emanuel's criteria (EMC)

Quality of evidence

7 EMC: Holistic assessments, Timing of PC

introduction, Patient's goals, Continuous goal

very low

adjustment, Suffering reduction, ACP, Last

hours of living care.

8 EMC: Discussion of illness limitations and prognosis, Holistic assessments, Timing of holistic assessments, Timing of PC introduction, Patient's goals, Continuous goal adjustment, Suffering reduction, Last hours of living care.

11 EMC: Discussion of illness limitations and prognosis, Holistic assessments, Timing of holistic assessments, Timing of PC introduction Patient's goals, Continuous goal adjustment, Suffering reduction, ACP, Involvement of PC team, Last hours of living care, Grief and bereavement care.

inpatient/outpatient 5 EMC: Discussion of illness limitations and prognosis, Holistic assessments, Suffering reduction, Involvement of PC team, Last hours of living care.

4 EMC: Timing of PC introduction, Suffering reduction, Involvement of PC team, Last hours of living care.

inpatient/outpatient 4 EMC: Timing of holistic assessments, Timing of PC introduction, Involvement of PC team, Last hours of living care.

4 EMC: Discussion of illness limitations and prognosis, Timing of PC introduction, Suffering reduction, Last hours of living care.

6 EMC: Holistic assessments, Timing of PC introduction, Suffering reduction, Involvement of PC team, Last hours of living care, Grief and bereavement care.

inpatient/outpatient 7 EMC: Holistic assessments, Timing of PC ntroduction, Suffering reduction, ACP, Involvement of PC team, Last hours of living care, Grief and bereavement care.

inpatient/outpatient 4 EMC: Holistic assessments, Suffering reduction, Involvement of PC team, Grief and bereavement care.

8 EMC: Holistic assessments, Patient's goals, Continuous goal adjustment, Suffering reduction, ACP, Involvement of PC team, Last hours of living care, Grief and bereavement care.

inpatient/outpatient 8 EMC: Holistic assessments, Patient's goals, Continuous goal adjustment, Suffering reduction, ACP, Involvement of PC team, Last hours of living care, Grief and bereavement care.

inpatient/outpatient 4 EMC: Holistic assessments, Patient's goals, ACP, Involvement of PC team

inpatient/outpatient 8 EMC: Holistic assessments, Timing of holistic assessments, Patient's goals, Suffering reduction, ACP, Involvement of PC team, Last hours of living care, Grief and bereavement care.
Low

High

Medium

High

Very Low

Low

Very low

High

Very low

Very low

Low

High

Low 


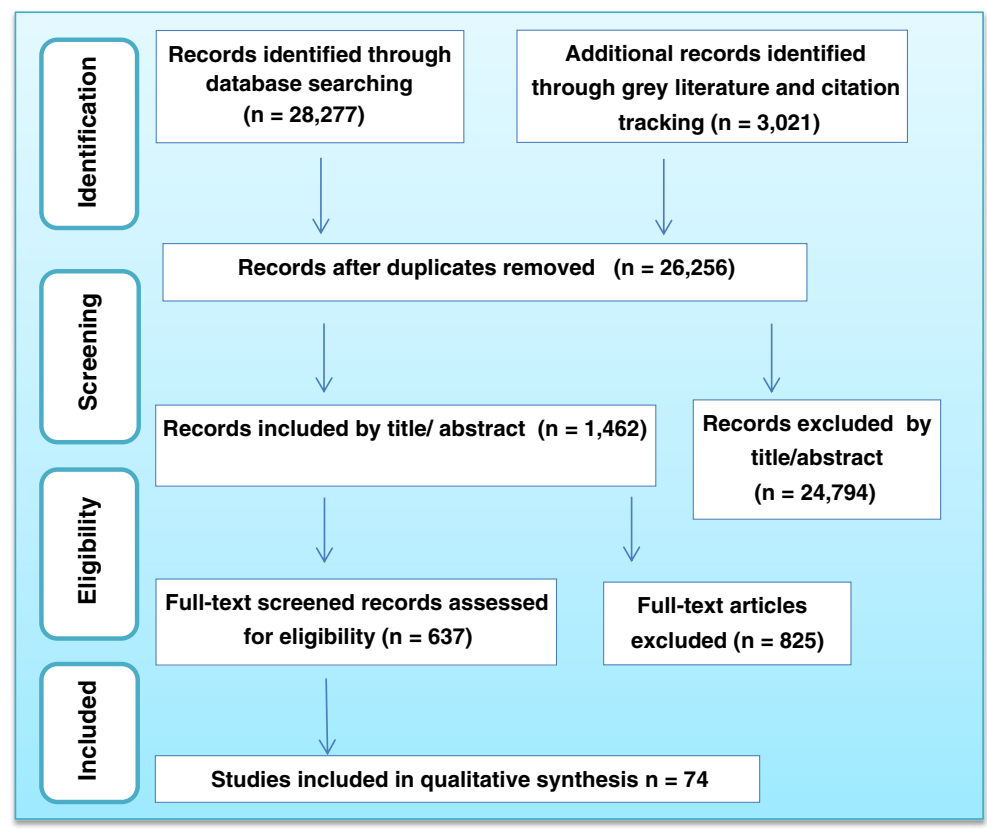

Fig. 1 Flow diagram of study selection procedure

and one pathway scored 11/11 whereas two others scored 10/11. These five studies were also ranked as of high quality evidence which means that they were developed based on both consensus and literature review. Of interest is that these five studies are not specific oncology guidelines, but PC or End of Life Care guidance. The guidelines/pathways that scored 10 or $11 / 11$ are presented and analysed in Table 5 and the strategies that they propose can be summarised as follows:

1) Discussion of illness limitations and prognosis: The guidelines/pathways agree that this can be realized through open and honest communication with patient and family, based on their needs and preferences, and enabling shared decision making. One pathway also suggests the employment of the surprise question or the Palliative Performance Scale can be used as triggers for initiating such discussions.

2) Holistic assessment: There is a unanimous consensus on the utilization of a combined physical, psychological, social and spiritual assessment.

3) Timing of the holistic assessments: Assessment should take place early in the disease trajectory. Further, it is recommended that holistic assessment should occur "at any time of day or night" for physical and psychological support and as long as possible for patient's social participation. Also, its realization should vary depending on changes in the disease or on the appearance of new symptoms and based on application of e.g. a 'distress thermometer'.
4) Exact timing of introducing PC: Three strategies are identified: i) the use of the surprise question, ii) the evaluation of the patient's and the family's needs, iii) illness stage - disease/cancer related prognostic indicators (e.g. like the indicators mentioned in the Gold Standards Framework).

5) Patient's goals assessments: All the guidelines/ pathways agree that this assessment should be based on the continuous communication between the patient and the PC specialists to identify patient goals.

6) Continuous goal adjustment: It is suggested that PC specialists regularly consult the patient and adjust goals accordingly.

7) Suffering reduction: The guidelines/pathways elaborate on the use of appropriate medication and strategies aimed in reducing both physical and psychological suffering.

8) Advance care planning (ACP): Decision making should be based on patient's wishes and preferences. One pathway proposes the identification of the ACP via the use of three models (covenant model, contract model or DNR code).

9) Involvement of PC team: All of the guidelines/ pathways strongly recommend the involvement or formation of a multidisciplinary PC team (consisting of physicians, nurses and other health professionals, psychologists, mental health counsellors, social workers, spiritual counsellors).

10) Care during the last hours of living: The following steps are recommended: identification of the dying 
Table 5 Top 5 ICP guidelines and pathways

\begin{tabular}{|c|c|c|c|c|c|}
\hline IPC criteria & $\begin{array}{l}\text { Clinical practice } \\
\text { guidelines on palliative } \\
\text { Care-Spain [42]. }\end{array}$ & $\begin{array}{l}\text { Guideline on the } \\
\text { palliative care } \\
\text {-Hungary [61]. }\end{array}$ & $\begin{array}{l}\text { Palliative care pathway } \\
\text { in General Practice } \\
\text { Country- Belgium [93]. }\end{array}$ & $\begin{array}{l}\text { General guidance } \\
\text { RCGP/RCN- UK [77]. }\end{array}$ & $\begin{array}{l}\text { CMG42 End of life care } \\
\text { for adults-UK [79]. }\end{array}$ \\
\hline $\begin{array}{l}\text { Discussion of } \\
\text { illness limitations } \\
\text { and prognosis. }\end{array}$ & $\begin{array}{l}\text { Communication should } \\
\text { be based on patients' } \\
\text { and their family's needs } \\
\text { rather than the expected } \\
\text { survival time. }\end{array}$ & $\begin{array}{l}\text { Information about the } \\
\text { illness, decision } \\
\text { making, and } \\
\text { discussions about } \\
\text { death should be } \\
\text { based on the } \\
\text { patient's needs. }\end{array}$ & $\begin{array}{l}\text { Description of surprise } \\
\text { question and Palliative } \\
\text { Performance Scale (PPS) } \\
\text { to define prognosis or } \\
\text { when to enter PC } \\
\text { services. }\end{array}$ & $\begin{array}{l}\text { Open and honest } \\
\text { communication. } \\
\text { Identification of triggers } \\
\text { for discussion. Shared } \\
\text { decision making. }\end{array}$ & $\begin{array}{l}\text { Open communication } \\
\text { and offering of } \\
\text { information taking in } \\
\text { account always the } \\
\text { patient's and family's } \\
\text { needs. }\end{array}$ \\
\hline $\begin{array}{l}\text { Holistic } \\
\text { assessment. }\end{array}$ & $\begin{array}{l}\text { Integral, frequent } \\
\text { assessment in a } \\
\text { multidisciplinary, } \\
\text { individualized manner } \\
\text { for: symptoms, pain, } \\
\text { opioids use, spiritual } \\
\text { needs, grief. }\end{array}$ & $\begin{array}{l}\text { Whole patient } \\
\text { assessment should } \\
\text { include physical, } \\
\text { psychosocial, and } \\
\text { spiritual dimensions, } \\
\text { according to the } \\
\text { nature of the illness. }\end{array}$ & $\begin{array}{l}\text { Recommendations on } \\
\text { how to assess patients } \\
\text { and how to deal with } \\
\text { their physical, } \\
\text { emotional, } \\
\text { psychological, social } \\
\text { and spiritual issues. }\end{array}$ & $\begin{array}{l}\text { Holistic approach: } \\
\text { physical, psychological, } \\
\text { social, practical and } \\
\text { emotional, religious and } \\
\text { spiritual support. }\end{array}$ & $\begin{array}{l}\text { Holistic approach: } \\
\text { physical, psychological, } \\
\text { social, emotional and } \\
\text { spiritual support. Use of } \\
\text { the Gold Standard } \\
\text { Framework (GSF). }\end{array}$ \\
\hline $\begin{array}{l}\text { Timing for holistic } \\
\text { assessments }\end{array}$ & Not included & $\begin{array}{l}\text { assessment takes } \\
\text { place at the first } \\
\text { appointment. Further } \\
\text { assessments depends } \\
\text { on changes in the } \\
\text { disease trajectory. }\end{array}$ & $\begin{array}{l}\text { Whenever the patient is } \\
\text { seen by the GP or nurse } \\
\text { using the 'distress } \\
\text { thermometer'. }\end{array}$ & $\begin{array}{l}\text { At any time of day or } \\
\text { night for physical and } \\
\text { psychological support } \\
\text { and as long as possible } \\
\text { for the social } \\
\text { participation. }\end{array}$ & $\begin{array}{l}\text { At any time of day or } \\
\text { night for physical and } \\
\text { psychological support } \\
\text { and as long as possible } \\
\text { for the social } \\
\text { participation. }\end{array}$ \\
\hline $\begin{array}{l}\text { Timing for PC } \\
\text { introduction }\end{array}$ & $\begin{array}{l}\text { Interventions based } \\
\text { on the patients \&their } \\
\text { family's needs. PC } \\
\text { services should be } \\
\text { guaranteed when } \\
\text { necessary. }\end{array}$ & Not included & $\begin{array}{l}\text { Surprise Question: } \\
\text { "Would you be } \\
\text { surprised if your patient } \\
\text { were to die in the next } \\
\text { months, weeks, days?". }\end{array}$ & $\begin{array}{l}\text { Ask the Surprise } \\
\text { Question "Would you be } \\
\text { surprised if the patient } \\
\text { were to die in the next } \\
\text { months, weeks or } \\
\text { days?". }\end{array}$ & $\begin{array}{l}\text { Timely access to } \\
\text { generalist and specialist } \\
\text { PC services on the basis } \\
\text { of need and not } \\
\text { diagnosis. }\end{array}$ \\
\hline
\end{tabular}

Patient's goals Decision-making should assessments

Continuous goal adjustment

Suffering reduction

Advance care planning (ACP). be enhanced through the life goals and personal values.

Needs on information and preferences of the patient should be assessed regularly.

Evaluation of the pain, instructions and involvement of patient in the use of analgesics and opioids depending of the pain stage and features.

Explore patient's wishes and goals. Previous guidelines, wishes of the patient saved in his clinical records, legal and the nearest in charge relatives should be considered.
Patient's goals for care should be brought to light.

Patients have the right for modifying the plan based according to their needs. Interventions should be adapted to patient's goals.

Medical aspect of PC \& applicable therapies, special treatments \& interventions to reduce suffering (physical psychosocial suffer symptoms).

\section{Patients have the} right to information and autonomy/selfdetermination, refusal of treatments, \& the process of making a living will
At the time of the holistic assessment, patients goals need to be assessed too.

Whenever there are changes in the disease trajectory patients goals need to be reassessed.

Regular review of patients' and carers' needs and preferences.

Discussions with patients and their carers about their future needs. This should be done as often as it feels that is needed.

Should meet physical and psychological needs at any time of day or night, including access to medicines and equipment.

Help the patients identify the choices that they may face, assist them to record their decisions and ensure that their wishes are fulfilled. Recognition of wishes for resuscitation organ donation and place of death.

Multidisciplinary generalist and specialist PC services should provide care over a 24 h period for people approaching the end of life.
Open conversations and clear expression of the end-of-life patients and their needs.

Patients and carers should be offered holistic assessments in response to their changing needs and preferences.

End of life patients should have their physical and psychological needs met at any time of day or night, including access to medicines and equipment.

Increasing choice and personalization through ACP including advance decisions to refuse treatment and provision of resources that enable these choices.

Specialist multidisciplinary PC team should be responsive to emergency need and able to admit people approaching the end of life at any time 
Table 5 Top 5 ICP guidelines and pathways (Continued)

\begin{tabular}{|c|c|c|c|c|c|}
\hline $\begin{array}{l}\text { Recommendations } \\
\text { on care during the } \\
\text { last hours of living. }\end{array}$ & $\begin{array}{l}\text { Recommendations } \\
\text { include information, } \\
\text { explanations, symptoms } \\
\text { treatment, care } \\
\text { continuity and holistic } \\
\text { approach. }\end{array}$ & $\begin{array}{l}\text { Symptoms and signs } \\
\text { of death, reducing } \\
\text { medication, nutrition, } \\
\text { and fluid intake } \\
\text { during the last hours } \\
\text { of life. }\end{array}$ & $\begin{array}{l}\text { Contains a separate } \\
\text { section on how to } \\
\text { identify the dying } \\
\text { phase, communication, } \\
\text { support, symptom } \\
\text { control. }\end{array}$ & $\begin{array}{l}\text { Identification of the } \\
\text { dying phase (use of } \\
\text { Patient Charter). Support } \\
\text { for patient and carer. } \\
\text { Use of the Liverpool } \\
\text { Care Pathway. }\end{array}$ & $\begin{array}{l}\text { Co-ordinated care across } \\
\text { all relevant settings at } \\
\text { any time, based on the } \\
\text { person's current medical } \\
\text { condition, advance care } \\
\text { planning and } \\
\text { preferences. }\end{array}$ \\
\hline $\begin{array}{l}\text { Grief and } \\
\text { bereavement care } \\
\text { recommendations. }\end{array}$ & $\begin{array}{l}\text { Identification of } \\
\text { bereavement risk; } \\
\text { interventions according } \\
\text { to the nature of the } \\
\text { grief, with professionals } \\
\text { trained to deal with } \\
\text { these issues. }\end{array}$ & $\begin{array}{l}\text { Methods, aims and } \\
\text { outcomes of } \\
\text { bereavement } \\
\text { counselling are } \\
\text { described in the } \\
\text { guideline. }\end{array}$ & $\begin{array}{l}\text { Consultation after } \\
\text { death, differentiation } \\
\text { between depression, } \\
\text { normal and } \\
\text { complicated grief. }\end{array}$ & $\begin{array}{l}\text { Timely verification and } \\
\text { certification of death. } \\
\text { Practical and emotional } \\
\text { bereavement support } \\
\text { for carer or family. }\end{array}$ & $\begin{array}{l}\text { Immediate and ongoing, } \\
\text { emotional, bereavement } \\
\text { \& spiritual support as } \\
\text { appropriate to the needs } \\
\text { and preferences of the } \\
\text { carer/family. }\end{array}$ \\
\hline
\end{tabular}

phase, communication, support based on patients and family's needs and wishes and symptom control.

11) Grief and bereavement care: The main proposed strategy involves the immediate and ongoing bereavement, emotional and spiritual support appropriate to the family's needs and preferences.

The point at which PC should be introduced in the disease trajectory and which referral criteria should apply was addressed in less than half of the total of the included guidelines and pathways. This could be seen to have a significant impact on the benefits of PC if not introduced to patients in a timely manner. In view of this, it is surprising that $59 \%(n=43)$ of all the included guidelines/pathways did not discuss (adequately or at all) referral criteria.

The distribution of the guidelines/pathways that explicitly mentioned the referral criteria shows that $8 \%$ recommended that the referral criterion should be for terminally ill people without specifying the exact timing. Further, $7 \%$ reported that the referral criteria should be located in the last 6 months. Also, $4 \%$ of the guidelines reported as a referral criterion the surprise question ("Would I be surprised if this patient died in the next year?") whereas $8 \%$ the reference of fulfilment of specific prognostic criteria mentioned in the Gold Standards Framework or Stadium IVB [106, 107]. The presence of metastatic disease was considered as a referral criterion by $15 \%$ of all the studies whilst $13 \%$ suggested the application of the guidelines as soon as the diagnosis of cancer has been made. Finally, one guideline recommended that the referral criteria should be determined upon a discussion with the patient and the family.

\section{Discussion}

The results of the systematic review identified 74 guidelines/pathways fulfilling our inclusion criteria. Geographically, the majority of the included studies originated from the UK. Moreover, only five of them scored at least 10/11 of the IPC criteria.
Although there is significant improvement in cancer treatment, still half of all patients with cancer will eventually die of their disease and in one third this will happen within 6 months of diagnosis [108]. Currently, European and American oncology organisations such as ASCO, ESMO, and $\mathrm{NCCN}$, recommend the early integration of PC for patients with cancer [2, 109]. These recommendations have been evidenced by studies that corroborate the positive relationship between early integration of PC and improvements in the quality of life of the patients, leading to better patient and caregiver outcomes, improvement of symptoms and patient satisfaction, with reduced caregiver burden, and reduced use of futile interventions [3, 12, 110-112]. Despite this evidence, cancer patients tend to be referred to PC late in their disease trajectory [12]. The implementation of PC integration is highly dependent on staff perception (misconception) of PC that often gets mistaken for terminal care [113].

The guidelines and pathways made a number of recommendations about how to introduce pc into oncology care. These included recommendations on how PC can be implemented earlier in oncology care are education of providers and public about the importance of PC and to coordinate $\mathrm{PC}$ efforts through strengthening affiliations and/or developing new partnerships [114]. One way to educate clinicians would be the integration of PC in disease specific guidelines.

According to our findings, most of the included guidelines/pathways recommend the need of a holistic PC approach e.g. a whole patient assessment. Additionally, it is also recognised that the reduction of suffering by implementing specific PC interventions e.g. use of opioids or analgesics, should be among the primary goals of integrated PC. This is in agreement with empirical evidence that illustrate the advantages of both the holistic approach and the focus on the reduction of suffering $[115,116]$.

A noteworthy outcome has been the general shortage in the guidelines of information on the specification on 
when PC should be initiated (PC referral criteria). Moreover, even among those guidelines/pathways that comment on the timing of referral, there is great variability e.g. surprise question, life expectancy less than 6 months, presence of metastatic disease, etc. We consider this important because clear referral criteria enable the initiation of the guideline/pathway. Consequently, this is correlated with the overall efficiency of a guideline/pathway. The notable absence of references to the referral criteria and the strong disagreement between those that mention them deserve further exploration.

More generally, there is a growing recognition that the PC should be considered around the time of diagnosis [117]. However, available research hints that that these recommendations alone are not sufficient for the practical determination of the referral criteria [118, 119]. With regard to cancer, a robust definition of the referral criteria is quite cumbersome and detailed and systematic methods need further development [113]. NCCN states that all patients should be screened for PC needs at their initial visit, at appropriate intervals and as clinically indicated [8]. For ASCO's Panel's expert consensus combined standard oncology care and palliative care should be considered early in the course of illness for any patient with metastatic cancer and/or high symptom burden [12]. In Germany, Gaertner et al. developed diagnosis specific guidelines for 19 malignancies to identify a disease- specific point in each disease trajectory to initiate palliative care [11]. In view of the above, we conclude that the establishment of PC referral criteria in guidelines for cancer patients remains an elusive and contentious topic which demands further attention.

Interestingly, guidelines/pathways give less attention to advance care planning, grief and bereavement support for the family members, and continuity of care. This outcome is surprising because the significance of these aspects has been highlighted by several studies $[9,120,121]$. Oncologists have to give their patients clear and consistent prognostic information as this will help facilitate discussions about patients' end of life care preferences. Fears among oncologists that early PC consultation will frighten their patients are unfounded and the opposite has been proven [122]. Oncologists must ensure that advance care plans are in place as early as possible in the disease trajectory [8]. Bereavement support is gaining attention in the oncology field, with the NCCN guidelines being the first guideline that sees afterdeath care for the family as an essential part of the continuum of cancer care [8].

With the exception of the referral criteria, the holistic approach and the reduction of suffering, the compliance with Emmanuel's IPC criteria of the included guidelines/pathways varies widely. In turn, this implies that the fulfilment of integrated PC criteria is generally not taken into consideration when designing cancer guidelines/pathways. Previous studies looking at End-ofLife care content in medical textbooks and in treatment guidelines for life-limiting disease already revealed that top-selling textbooks and guidelines on chronic, life-limiting illnesses offer little information on caring for patients at the end of life [123]. Our findings reveal that five of the guidelines/pathways fulfilled at least 10 out of 11 IPC criteria (in fact three fulfilled all 11 criteria).

A closer look at the content of these guidelines has shown that they offer similar recommendations on IPC (Table 5). This has a three-fold importance. First it affirms that these five guidelines can serve as a benchmark for PC integration in cancer guidelines. Second, it hints that for all the guidelines/pathways that scored moderately or low, there is a considerable room for improvement. Finally, it supports the appropriateness of using Emanuel's tool for the evaluation of the PC content of guideline data.

To conclude, it can be inferred that, even though small discrepancies do exist, the strategies proposed by the guidelines/pathways that scored the highest have strong content similarity. In turn, this suggests that there is a common conception concerning the incorporation of integrated PC into the framework for guidelines/pathways.

Finally, it is important to reiterate that we should differentiate between the completeness of guidelines/pathways content and its performance following its clinical implementation. Although a correlation between the two is quite likely to exist, a high score with respect to Emmanuel's criteria cannot be considered to necessarily speculate on the efficacy of the guidelines/pathways in the clinical context. Future research could explore the clinical utility of these top guidelines/pathways.

\section{Study limitations}

As is the case with any study that aspires to conduct a systematic literature review, a major limitation stems from the choice of the search strategy. We started with a broad search not only focussing on cancer but also on chronic disease. The results of the latter will be the subject of a subsequent article. More specifically, the search of the electronic databases returned a large amount of articles, many of which originated outside Europe.

In general, there is a lack of standardised definitions regarding integrated PC [8]. For the needs of this study, we furnished our own functional definition. However, our results might differ if a different definition had been employed.

An additional limitation stems from the confinement to guidelines/pathways published in Dutch, English, 
French, German, Hungarian and Spanish. Hence, one may not exclude the possibility that more guidelines and pathways exist in other languages spoken in the EU.

As mentioned above, the evaluation of the content of the guidelines/pathways used Emmanuel's criteria. The authors of this study, in collaboration with all the InSup$\mathrm{C}$ project partners, decided to use this tool on the basis of its apparent completeness. Therefore, one may not exclude the possibility that a different assessment tool would lead to a different score of the guidelines/pathways and thus a different hierarchy. Additionally, we only performed a limited analysis of the content of recommendations of IPC based on the most complete guidelines for PC according to Emmanuel's criteria.

Finally, the fact that we included only guidelines that included only two or more of the 11 Emanuel's IPC criteria might have skewed the results favouring a more positive view of integration of $\mathrm{PC}$ in oncology care in Europe.

\section{Conclusions}

Five studies were found to fulfil at least 10/11 of the IPC criteria for completeness on IPC. These guidelines/pathways proposed very similar strategies for the realization of these criteria and were based on high levels of evidence. Consequently, they could serve as benchmarks of how PC can be integrated in cancer guidelines. As such, they also can provide a base to further investigate what constitutes integrated PC in cancer.

Our systematic review has revealed the importance of a holistic approach and interventions aimed at reducing suffering by deploying an integrated palliative care approach. Additionally, our results illustrate that there is disagreement on the appropriate referral criteria for IPC which remains a contentious and challenging topic in terms of the integration of PC in cancer care.

As mentioned above, the included guidelines/pathways do not embody aspects of implementation. Therefore, even though the theoretical framework of these guidelines/pathways conforms reasonably well to the state of the art in IPC, their applicability in practice needs to be further investigated.

Overall, our findings have identified both the strengths and the weaknesses of the available guidelines and pathways in Europe for patients with cancer in terms of the integration of palliative care. Consequently, we anticipate that our findings may inform physicians and policy makers as a framework in their efforts to improve the integration of $\mathrm{PC}$ in the care of people with cancer.

\section{Ethics/research governance approval}

This is a systematic review of primary studies. Further ethical approval is not applicable.
Competing interests

The authors declare that they have no competing interest.

\section{Authors' contributions}

KVB was involved in conception and design of the study; acquisition of data; analysis and interpretation and drafting of manuscript. NS was involved in conception and design of the study; acquisition of data; analysis and interpretation of manuscript. NP was involved in conception and design of the study; analysis and interpretation of data and critical revision of manuscript. JGH was involved in conception and design of the study, analysis and interpretation of data and critical revision of manuscript. SH was involved in conception and design of the study; acquisition of data; analysis and interpretation of data. EG did acquisition of data; analysis and

interpretation of data. MEE did acquisition of data; analysis and interpretation of data. IR did acquisition of data; analysis and interpretation of data. FH did acquisition of data; analysis and interpretation of data. AC was involved in conception and design of the study; analysis and interpretation and critical revision of manuscript. CC was involved in conception and design of the study; acquisition of data; analysis and interpretation and critical revision of manuscript. LR was involved in conception and design of the study; analysis and interpretation and critical revision of manuscript. SP was involved in conception and design of the study; analysis and interpretation of data and critical revision of manuscript. JM was involved in conception and design of the study; analysis and interpretation of data and critical revision of manuscript. All authors read and approved the final manuscript.

\section{Acknowledgements}

We would like to specially thank Juliano Ferreira Arcuri, Marieke Groot (Radboud University, the Netherlands), Eva Dybek (University Hospital Bonn, Germany), Benjamin Ewert (University Hospital Bonn, Germany), Csilla Busa (University of Pécs Medical School, Hungary) and Zsuzsanna Kiss (University of Pécs Medical School, Hungary) for their assistance with collecting, screening and extracting the grey literature. Additionally, we would like to thank Jelle van Gurp (Radboud University, the Netherlands) for his help in creating the evaluation tool for the content of the guidelines/pathways based on the Emanuel's ICP criteria. Finally, we thank Jeroen van Wijngaarden (Erasmus University Rotterdam, the Netherlands) for offering his advice and guidance for this study.

\section{Funding}

"InSup-C, Patient-centered integrated palliative care pathways in advanced cancer and chronic disease", is funded by the European Union Seventh Framework Programme (FP7/HEALTH, under grant agreement 305555). InSup-C aims to identify the prerequisites for best practice in integrated palliative care with the overall objective of improving service delivery and service user outcomes. InSup-C is coordinated by Dr Jeroen Hasselaar of Radboud University Medical Center, Nijmegen, the Netherlands. Other partners are: University Hospital, Bonn, Germany; International Observatory on End-of-Life Care, Lancaster University, Lancaster and Sheffield University, United Kingdom; University of Pecs Medical School, Pecs, Hungary; University Hospital Leuven, Leuven, Belgium; World Health Organization, Geneva, Switzerland; European Association for Palliative Care (EAPC OnLus), Milan, Italy; Erasmus University, Rotterdam, The Netherlands; University of Navarra, Pamplona (Navarra), Spain; Mount Sinai Medical Center, New York, USA.

\footnotetext{
Author details

'Department of Radiation-Oncology and Palliative Medicine, University Hospital Gasthuisberg, Leuven, Belgium. ${ }^{2}$ International Observatory on End of Life Care, Division of Health Research Lancaster University, Lancaster, United Kingdom. ${ }^{3}$ Department of Anesthesiology, Pain and Palliative Medicine, Radboud University Nijmegen Medical Centre, Nijmegen, The Netherlands. ${ }^{4}$ Department of Palliative Medicine, University Hospital Bonn, Bonn, Germany. ${ }^{5}$ Department of Palliative Medicine, University of Navarra Hospital, Pamplona, Navarra, Spain. ${ }^{6}$ Faculty of Medicine, Institute of Family Medicine, University of Pécs Medical School, Pécs, Hungary.
}

Received: 28 January 2016 Accepted: 23 February 2016 Published online: 03 March 2016 


\section{References}

1. Data from Statistics, European Commission, Eurostat, 2014. http://ec.europa. eu/health/major_chronic_diseases/diseases/cancer/index_en.htm. assesed December 2012

2. Temel JS, Greer JA, Muzikansky A, Gallagher ER, Admane S, Jackson VA, Dahlin CM, Blinderman CD, Jacobsen J, Pirl WF, et al. Early palliative care for patients with metastatic non-small-cell lung cancer. N Engl J Med. 2010; 14(8):733-42.

3. Mazanec P, Daly BJ, Pitorak E, et al. A new model of palliative care for oncology patients with advanced disease. J Hosp Palliat Nurs. 2009;11:324-31.

4. Murray SA, Kendall M, Boyd K, Sheikh A. Illness trajectories and palliative care. BMJ. 2005;330:1007-11.

5. Zimmermann C, Swami N, Krzyzanowska M, et al. Early palliative care for patients with advanced cancer: a cluster-randomised controlled trial. Lancet. 2014:383:1721-30

6. Bakitas M, Lyons KD, Hegel MT, et al. Effects of a palliative care intervention on clinical outcomes in patients with advanced cancer: the Project ENABLE Il randomized controlled trial. JAMA. 2009;302:741-9.

7. World Health Organization. World Health Organization Definition of Palliative Care. http://www.who.int/cancer/palliative/definition/en/. (accessed Mar, 2012).

8. European Society for Medical Oncology (ESMO) Palliative Care Working Group. Available at: http://www.esmo.org/About-Us/Who-We-Are/EducationalCommittee/Palliative-Care-Working-Group. (accessed 06-01-2014).

9. Hui D, Mori M, Parsons HA, et al. The lack of standard definitions in the supportive and palliative oncology literature. J Pain Symptom Manage. 2012;43(3):582-92.

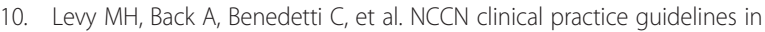
oncology: palliative care. J Natl Compr Canc Netw. 2009;7:436-73.

11. European Association for Palliative Care (EAPC). Professional integration; 2014 [accessed 06-01-2014]. Available from: http://www.eapcnet.eu/ Themes/Policy/Professionalintegration.aspx.

12. McCusker M, Ceronsky L, Crone C, Epstein H, Greene B, Halvorson J, Kephart K, Mallen E, Nosan B, Rohr M, Rosenberg E, Ruff R, Schlecht K, Setterlund L. Institute for Clinical Systems Improvement ICSI. Health Care Guideline. Palliative care for Adults. 2013 [assessed Nov 2014]. Available from: https://www.icsi. org/_asset/k056ab/PalliativeCare.pdf

13. Gaertner J, Wolf J, Hallek M, et al. Standardizing integration of palliative care into comprehensive cancer therapy - a disease specific approach. Support Care Cancer. 2011;19:1037-43.

14. Foley KM, Gelband H. Improving Palliative Care for Cancer. Washington: Institute of Medicine and National Research Council; 2001.

15. Higginson IJ, Sen-Gupta GJ. Place of care in advanced cancer: a qualitative systematic literature review of patient preferences. J Palliat Med. 2000;3(3):287-300.

16. Beccaro M, Costantini M, Giorgi Rossi P, Miccinesi G, Grimaldi M, Bruzzi P, ISDOC Study Group. Actual and preferred place of death of cancer patients. Results from the Italian survey of the dying of cancer (ISDOC). J Epidemiol Community Health. 2006;60(5):412-6.

17. Gomes B, Higginson IJ. Where people die (1974-2030): past trends, future projections and implications for care. Palliat Med. 2008;22(1):33-41.

18. Abarshi E, Echteld M, Van den Block L, Donker G, Deliens L, OnwuteakaPhilipsen $B$. Transitions between care settings at the end of life in the Netherlands: results from a nationwide study. Palliat Med. 2010;24(2):166-74.

19. Van den Block L, Deschepper R, Bilsen J, Van Casteren V, Deliens L. Transitions between care settings at the end of life in belgium. JAMA. 2007;298(14):1638-9.

20. Broekhuis D, Kuin $Y$, Verhagen CAHHVM, Vissers KCP, Prins JB. Mantelzorgers van oncologiepatiënten in de palliatieve fase: Ervaren belasting en coping. Nederlands-VlaamsTijdschriftvoorPalliatieveZorg. 2008;3:69-75

21. Jacobs P, Dumont S, Turcotte $V$, Anderson D. Evaluating the economic loss of caregiving forpalliative care patients. J Palliat Care. 2011;27(3):210-5.

22. Edwards SB, Olson K, Koop PM, Northcott HC. Patient and family caregiver decision making in the context of advanced cancer. Cancer Nurs. 2012;35(3):178-86.

23. Payne S. EAPC Task Force on Family Carers White Paper on improving support for family carers in palliative care: part 2. EJPC. 2010;17(6):286-90.

24. National Consensus Project for Quality Palliative Care: Clinical Practice Guidelines for Quality Palliative Care, Second Edition; 2009. [assesed Dec 2015] Available from: http://www.nationalconsensusproject.org/NCP_ Clinical_Practice_Guidelines_3rd_Edition.pdf.
25. Grant M, Elk R, Ferrell B, Morrison RS, von Gunten CF. Current status of palliative care - clinical implementation, education, and research. CA Cancer J Clin. 2009;59(5):327-35.

26. Mast KR, Salama M, Silverman GK, Arnold RM. End-of-life content in treatment guidelines for life-limiting diseases. J Pall Med. 2004;7(6):754-73.

27. Calman K, Hine D. A policy framework for commissioning cancer services. A report by the Expert Advisory Group on Cancer to the Chief Medical Officers of England and Wales. London: Department of Health; 1995.

28. Emanuel L, Alexander C, Arnold RM, Bernstein R, Dart R, Dellasantina C, Dykstra L, Tulsky J. Integrating palliative care into disease management guidelines. J Palliat Med. 2004;7(6):774-83.

29. Hawker S, Payne S, Kerr C, Hardey M, Powell J. Appraising the evidence: reviewing disparate data systematically. Qual Health Res. 2002;12:1284-299.

30. National Institute for Health and Care Excellence. https://www.nice.org.uk/ guidance (accessed Oct, 2014).

31. Guideline Program of Oncology of the AWMF, Deutsche Krebsgesellschaft e. V., Deutsche Krebshilfe e. V. Interdisciplinary guideline of quality S3 for early detection, diagnosis and treatment of different stages of prostate cancer; 2011 [assessed Sept 2013]. Available from: https://www.urologenportal.de/ fileadmin/MDB/PDF/S3_LL_PCAS3_PCa_Aktualisierung_2011_110912f.pdf.

32. Bergert FW, Braun M, Clarius H, Ehrenthal K, Feßler J, Gross J, Gundermann K, Hesse H, Hintze J, Hüttner U, Kluthe B, LangHeinrich W, Liesenfeld A, Luther E, Pchalek R, Seffrin J, Sitte T, Sterzing A, Vetter G, Wolfring H-J, Zimmermann U, Gärtner J, Ostgathe C, Voltz R. Practice guideline for palliative care. 2009 [assessed Sept 2013]. Available from: http://www.pmvforschungsgruppe.de/ pdf/03_publikationen/palliativ_ll.pdf.

33. Guideline Program of Oncology of the AWMF, Deutsche Krebsgesellschaft e.V., Deutsche Krebshilfe e.V. Interdisciplinary S3 guidelines for the diagnosis, treatment and follow-up of breast cancer; 2012 [assessed Dec 2013]. Available from: http://www.awmf.org/uploads/tx_szleitlinien/032-045OL_k_S3 Brustkrebs_Mammakarzinom_Diagnostik_Therapie_Nachsorge_2012-07.pdf.

34. Goeckenjan G, et al., ed. German Respiratory Society and the German Cancer Society, AWMF. Prevention, Diagnosis, Therapy, and Follow-up of Lung Cancer. 2010; [assessed Sept 2013]. Available from: https://www. thieme.de/statics/dokumente/thieme/final/de/dokumente/zw_pneumologie/ Lungenkarzinom_S3.pdf.

35. Guideline Program of Oncology of the AWMF, Deutschen Krebsgesellschaft e.V., Deutschen Krebshilfe e.V. Malignant melanoma S3-guideline: Diagnosis, treatment and aftercare of melanoma; 2013 [assessed Sept 2013]. Available from: http://www.krebsgesellschaft.de/download/s3-melanom-ol-kurzversion-v1.1.pdf.

36. Medicines Commission of the German Medical Association. Cancer pain; 2007 [assessed Dec 2013]. Available from: http://www.akdae.de/ Arzneimitteltherapie/TE/A-Z/PDF/Tumorschmerz.pdf.

37. Federal Joint Committee. Directive of the Federal Joint Committee on the Regulation of specialized outpatient palliative care (Specialty Outpatient palliative supply policy/SAPV RL); 2007 [assessed Sept 2013].

38. Peeters M, Vlayen J, Stordeur S, Mambourg F, Boterberg T, de Hemptinne B, Demetter P, Deprez P, Gigot JF, Hoorens A, Van Cutsem E, Van den Eynden B, Van Laethem JL, Verslype C. National Practice Guideline pancreatic cancer. 2009 [assessed Jan 2014]. Available from: http://kce.fgov.be/sites/default/files/ page_documents/d20091027310.pdf.

39. Wauters I, Robays J, Verleye L, Holdt Henningsen K, Hulstaert F, Berghmans T, De Wever W, Lievens Y, Pauwels P, Stroobants S, Van Houtte P, Van Meerbeeck J, Van Schil P, Weynand B, De Grève J. Small cell and non- small cell lung cancer: diagnosis, treatment and follow-up. 2013 [assessed Jan 2014]. Available from: http://kce.fgov.be/sites/default/files/page_documents/KCE_206_lung_cancer.pdf.

40. Lerut T, Stordeur S, Verleye L, Vlayen J, Boterberg T, De Hertogh G, De Mey J, Deprez P, Flamen Pattyn P, Van Laethem JL, Peeters M. National Practice Guideline of oesophageal and stomach cancer - UPDATE. 2012 [assessed Jan 2014]. Available from: http://kce.fgov.be/sites/default/files/page_documents/ KCE_179A_update_slokdarm-en_maagkanker.pdf.

41. Revuelta C, Sánchez P, Somoza E, López P. Palliative Care Unit: Standards and Recommendations. 2009 [assessed Nov 2013]. Available from: http:// www.msssi.gob.es/organizacion/sns/planCalidadSNS/docs/ cuidadospaliativos.pdf.

42. Arrieta Ayestarán M, Balagué Gea L, Bañuelos Gordon A, Clavé Arruabarrena E, Egaña Otaño L, Etxeberria Agirre A, García García J, Merino Moreno JL, Millet Sampedro M, Rotaeche del Campo R, Sagarzazu Goenaga JJ, Salán Puebla JM, Agud Aparicio JM, Alonso Babarro A, Altuna Basurto E, Apezetxea Ezelaya A, Arce García C, Arrizabalaga Arrizabalo MJ, Astudillo Alarcón W, Barbero Gutiérrez J, Berdún Cheliz MA, Boceta Osuna J, Campo Guiral MA, Centeno Cortés C, 
Espínola García, E, Gómez Rodríguez de Mendarozqueta M, Gómez-Batiste Alentorn X, Gómez Sancho M, Gnzález Barón M, Herrera Molina E, lribar Sorazu J, Lizarraga Mansoa S, López Vivanco-Alda G, Muñoz Martínez T, Núñez Olarte JM, Olaizola Bernaola M, Ortega Villaro B, Palao Tarrero A, Pascual López A, Rocafort Gil J, Rodríguez Vega B, Sanz Ortiz J, Valderrama Ponce MJ, Vinuesa Acosta FJ, Rico Iturrioz R, Galnares Cordero L, Urbano Echávarri M. Clinical Practice Guidelines on Palliative Care; 2008 [assessed Nov 2013]. Available from: http// www.osakidetza.euskadi.eus/contenidos/informacion/osk_publicaciones/eu_ argital/adjuntos/lehen/cuidadosPaliativos.pdf.

43. Sociedad Espanola de Cuidados Paliativos. Palliative Care Guideline. [assessed Nov 2014]. Available from: http://www.msssi.gob.es/ organizacion/sns/planCalidadSNS/docs/cuidadospaliativos.pdf.

44. González San Segundo C, Núñez Olarte JM, Sanz Llorente B, Lacaste reverté MA, García Pérez C, Álvarez de Mon Soto M, López Timoneda F, Jimeno Sanz I, Colmenarejo Hernando JC, Valentín Maganto V, Murillo González MT, Ramos Cordero P, de Miguel Sánchez C, Moya Mir M, Aguilera Guzmán M, Castro Bande A, Andradas Aragonés E. Palliative Care Guideline in the Community of Madrid; 2008 [assessed Nov 2013]. Available from: http://www.bioeticaweb. com/wp-content/uploads/2014/07/guia_paliativos.pdf.

45. Carvajal Sánchez C, Fernández González C, Fernández Vázquez A, Gago Argüelles L, Gómez Alvárez G, Granero Trancón J, Hevia García P, López Rivas L, Martínez Acebal A, Matallanas Bermejo M, Palacio Vázquez I, Riestra Menéndez S, Vallina Blanco J, Vieitez de Prado JM. Clinical recommendations guideline: colorectal cancer; 2006 [assessed Nov 2013]. Available from: http:/www. seapaonline.org/UserFiles/File/Ayuda\%20en\%20consulta/pcais/cancercolon.pdf.

46. van Zuylen L, van Veluw H, van Esch J. IKNL (Dutch Association of Comprehensive Cancer Centers). Guideline Care in the dying phase; 2010 [assessed Jan 2014]. Available from: http://www.oncoline.nl/uploaded/docs/ Zorg\%20in\%20de\%20stervensfase/RichtlijnStervensfase2009_0211\%20 (commentaarfase).pdf.

47. LWNO (National Work group Neuro-oncology), IKNL (Dutch Association of Comprehensive Cancer Centers). Guideline Leptomeningeal metastases (LM); 2010 [assessed Jan 2014]. Available from: http://www.google.be/url?sa=t\&rct=j $\& q=\&$ esr $c=s \& f r m=1 \&$ source $=$ web\& $c d=4 \&$ cad $=r j a$ inact $=8 \&$ ved $=0$ ahUKEwjz7 yn55zLAhXoDpoKHZBwBS4QFggwMAM\&url=http\%3A\%2F\%2Fwww.pallialine. nl\%2Frichtlijn\%2Fdoc\%2Fdownload.php\%3Fid\%3D468\&usg=AFQjCNECfD gU6bEyPCe6KhqcBn48Ypzzpw\&sig2=mWiSNt6kKs0XBMA7MAQyGQ.

48. IKNL (Dutch Association of Comprehensive Cancer Centers). Guideline Oncologic Rehabilitation; 2011 [assessed Jan 2014]. Available from: http://www.oncoline.nl/oncologische-revalidatie.

49. IKNL (Dutch Association of Comprehensive Cancer Centers). Guideline NSCLC; 2011 [assessed Jan 2014]. Available from: http://oncoline.nl/nietkleincellig-longcarcinoom.

50. IKNL (Dutch Association of Comprehensive Cancer Centers). Guideline Melanoma; 2013 [assessed Jan 2014]. Available from: http://www.google.be/

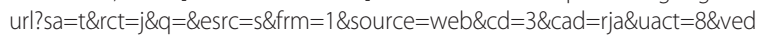
$=0$ ahUKEwiv_KLq55zLAhWoQJoKHfbtA0oQFggvMAl\&url=http\%3A\%2F\% 2Fwww.ariez.nl\%2FDownloadFile.lynkx\%3Fguid\%3Dd419b014-0a6d-4475aac0-c60b762fbeb6\&usg=AFQjCNFgm7CICFIFOIXpi7oQQYba4REGWQ\& sig2=d-OA4_HbATLWi2Eifw7QgQ

51. IKNL (Dutch Association of Comprehensive Cancer Centers). Guideline Oesophagus carcinoma; 2010 [assessed Jan 2014]. Available from: http://oncoline.nl/oesofaguscarcinoom.

52. IKNL (Dutch Association of Comprehensive Cancer Centers). Guideline Pancreas carcinoma; 2011 [assessed Jan 2014]. Available from: http://oncoline.nl/pancreascarcinoom.

53. IKNL (Dutch Association of Comprehensive Cancer Centers). Guideline cervix carcinoma; 2012 [assessed Jan 2014]. Available from: http://oncoline.nl/ cervixcarcinoom.

54. IKNL (Dutch Association of Comprehensive Cancer Centers). Guideline Endometrial carcinoma; 2011 [assessed Jan 2014]. Available from: http://oncoline.nl/endometriumcarcinoom.

55. IKNL (Dutch Association of Comprehensive Cancer Centers). Guideline Sarcoma carcino-sarcoma uterus; 2010 [assessed Jan 2014]. Available from: http://oncoline.nl/sarcoom-en-carcinosarcoom-van-de-uterus.

56. IKNL (Dutch Association of Comprehensive Cancer Centers). Guideline Guideline Hypo-pharynx carcinoma; 2010 [assessed Jan 2014]. Available from: http://oncoline.n//hypofarynxcarcinoom.

57. IKNL (Dutch Association of Comprehensive Cancer Centers). Guideline Larynx carcinoma; 2010 [assessed Jan 2014]. Available from: http://oncoline. nl/larynxcarcinoom.
58. IKNL (Dutch Association of Comprehensive Cancer Centers). Guideline Mouth and oropharynx carcinoma; 2004 [assessed Jan 2014]. Available from: http://oncoline.nl/mondholte-en-orofarynxcarcinoom.

59. IKNL (Dutch Association of Comprehensive Cancer Centers). Guideline Breast cancer [assessed Jan 2014]. Available from: http://oncoline.nl/ uploaded/docs/mammacarcinoom/ Dutch\%20Breast\%20Cancer\%20Guideline\%202012.pdf.

60. IKNL (Dutch Association of Comprehensive Cancer Centers). Guideline Prostate carcinoma; 2007 [assessed Jan 2014]. Available from: http:// oncoline.nl/prostaatcarcinoom.

61. Hungarian Hospice-Palliative Association. Professional Guideline (Directive) of the Hungarian Public Healthcare Ministry on the hospice and palliative treatment of adults and children with terminal cancer illness; 2013 [assessed Nov 2013]. Available from: https://kollegium.gyemszi.hu/conf/upload/ oldiranyelvek/APOLAS_terminalis\%20allapotu\%20daganatos\%20felnott\% 20es\%20gyermek\%20betegek\%20hospice\%20es\%20palliativ\%20ellatasarol_ mod0_v0.pdf.

62. Katalin Muszbek et al. Recommendations for the development of an integrative and complex palliative care in Hungary; 2013 [assessed Nov 201"].

63. National Institute for Clinical Excellence. Guidance on Cancer Services: Improving Supportive and Palliative Care for Adults with Cancer. National Institute for Clinical Excellence; 2004 [assessed Sep 2013]. Available from: https://www.nice.org.uk/guidance/csg4.

64. Scottish Executive. Making good care better: National practice statements for general palliative care in adult care homes in Scotland. Scottish Partnership for Palliative Care; 2006 [assessed Sep 2013]. Available from: http://www.palliativecarescotland.org.uk/content/publications/ Makinggoodcar-bette-CareHome-PracticStatements.pdf.

65. National Collaborating Centre for Cancer. The diagnosis and treatment of lung Cancer (updated). National Institute for Clinical Excellence; 2011 [assessed Sep 2013]. Available from: https://www.nice.org.uk/guidance/ cg121/evidence/full-guideline-181636957.

66. British Association of Otorhinolaryngology, Head and Neck Surgery. Head and Neck Cancer: Multidisciplinary Management Guidelines. ENTUK - British Association of Otorhinolaryngology, Head and Neck Surgery; 2011 [assessed Sep 2013]. Available from: http://bahno.org.uk/wp-content/uploads/2014/ 03/Multidisciplinary-Management-Guidelines-for-Head-and-Neck-Cancer.pdf.

67. Snowden J, Ahmedzai S, Ashcroft J, D'Sa S, Littlewood T, Low E, Lucraft H, Maclean R, Feyler S, Pratt G, Bird J. Haemato-oncology Task Force of the British Committee for Standards in Haematology and UK Myeloma Forum. Guidelines for supportive care in multiple myeloma 2011; 2011 [assessed Sep 2013]. Available from: http://www.ncbi.nlm.nih.gov/pubmed/21517805.

68. Thomas R, Richardsonz A. The NICE Guidance on Supportive and Palliative Care Implications for Oncology Teams; 2004 [assessed Sep 2013].

69. National Collaborating Centre for Cancer. Metastatic malignant disease of unknown primary origin. Diagnosis and management of metastatic malignant disease of unknown primary origin. National Institute for Health and Clinical Excellence; 2010 [assessed Sep 2013]. Available from: https:// www.nice.org.uk/guidance/cg104/documents/metastatic-malignant-diseaseof-unknown-primary-origin-prepublication-check-full-guideline2.

70. Healthcare Improvement Scotland. Palliative and End of Life Care Indicators; 2013 [assessed Jan 2014]. Available from: http://www.healthcareimprove mentscotland.org/our_work/person-centred_care/palliative_care/palliative_ care_indicators.aspx.

71. Gamondi C, Larkin P, Payne S. Core competencies in palliative care: an EAPC White Paper on palliative care education. Parts 1 \& 2; 2013 [assessed Jan 2014]. Available from: http://www.eapcnet.eu/LinkClick.aspx?fileticket=xctl28Ttfk=\&tabid=194 and http://www.eapcnet.eu/LinkClick. aspx?fileticket=getYk7bkpJ0=\&tabid=194.

72. Social Care Institute for Excellence. Dying well at home: the case for integrated working: Guide 48; 2013 [assessed Jan 2014]. Available from: http://www.scie.org.uk/publications/guides/guide48/.

73. Thomas K, Paynton D. RCGP commissioning guidance in end of life care : guidance for GPS, clinical commissioning group advisers; 2013 [assessed Jan 2014]. Available from: http://www.goldstandardsframework.org.uk/cdcontent/uploads/files/Primary\%20Care/ EOLC\%20Commissioning\%20Guidance\%20Final\%20-Apr13.pdf.

74. National End of Life Care Programme. Optimising the role and value of the interdisciplinary team: providing person centred end of life care; 2013 [assessed Jan 2014]. Available from: http://www.endoflifecare.nhs.uk/ download.ashx?mid=4984\&nid=4986. 
75. Durham and Darlington Council. Strategy for adult palliative and end of life care services; 2013 [assessed Jan 2014]. Available from: http://www. darlington.gov.uk/media/53051/End_of_Life_Strategy-Final_Draft.pdf.

76. Department of Health. End of Life Care Strategy: Fourth Annual Report; 2012 [assessed Jan 2014]. Available from: https://www.gov.uk/government/ uploads/system/uploads/attachment_data/file/136486/End-of-Life-CareStrategy-Fourth-Annual-report-web-version-v2.pdf.

77. Royal College of General Practitioners and Royal College of Nursing. Matters of life and death: helping people to live well until they die. General practice guidance for implementing the RCGP/RCN end of life care patient charter; 2012 [assessed Jan 2014]. Available from: http://www.goldstandards framework.org.uk/cd-content/uploads/files/Primary\%20Care/RCGP\%20 Matters\%20of\%20Life\%20Death\%20-\%20Jul12.pdf.

78. The College of Emergency Medicine. End of life care for adults in the Emergency Department; 2012 [assessed Jan 2014]. Available from: http://secure.collemergencymed.ac.uk/code/document.asp?ID=6285.

79. National Institute for Health and Care Excellence. CMG42 End of life care for adults; 2011 [assessed Jan 2014]. Available from: http://publications.nice.org.uk/ guide-for-commissioners-on-end-of-life-care-for-adults-cmg42.pdf.

80. Association for Palliative Medicine of Great Britain and Ireland, Consultant Nurse in Palliative Care Reference Group, Marie Curie Cancer Care, National Council for Palliative Care, and Palliative Care Section of the Royal Society of Medicine. Commissioning guidance for specialist palliative care : helping to deliver commissioning objectives; 2012 [assessed Jan 2014]. Available from: http://www. ncpc.org.uk/sites/default/files/CommissioningGuidanceforSpecialistPalliativeCare. pdf.

81. National End of Life Care Programme. Commissioning person centred end of life care; 2012 [assessed Jan 2014]. Available from: http://www.google.be/

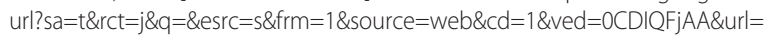
http\%3A\%2F\%2Fwww.nhsiq.nhs.uk\%2Fdownload.ashx\%3Fmid\%3D8628\% 26nid\%3D8627\&ei=VRMsU-v-EouThgetioCIBw\&usg=AFQjCNEETotobpHmA edEVnQZHZivqayx|Q\&bvm=bv.62922401,d.ZG4

82. National Institute for Health and Care Excellence. Quality standard for end of life care for adults; 2011 [assessed Jan 2014]. Available from: http://www. nice.org.uk/media/EE7/57/EoLCFinalQS.pdf.

83. National Institute for Health and Care Excellence. Advanced breast cancer: Diagnosis and treatment; 2009 [assessed Jan 2014]. Available from: https:// www.nice.org.uk/guidance/cg81.

84. Audit Scotland. Review of palliative care services in Scotland. 2008 [assessed Jan 2014]. Available from: http://www.audit-scotland.gov.uk/docs/health/ 2008/nr_080821_palliative_care.pdf.

85. NHS Scotland. Living and Dying Well: A national action plan for palliative and end of life care in Scotland. 2008 [assessed Jan 2014]. Available from: http://www.gov.scot/resource/doc/239823/0066155.pdf

86. National Collaborating Centre for Cancer. Metastatic spinal cord compression: Diagnosis and management of patients at risk of or with metastatic spinal cord compression; 2008 [assessed Jan 2014]. Available from: http://thorax.bmj.com/content/63/Suppl_1/i1.full.pdf.

87. National Audit Office. End of life care; 2008 [assessed Jan 2014]. Available from: http://www.nao.org.uk/wp-content/uploads/2008/11/07081043.pdf.

88. Scottish Executive. National Care Standards: Hospice Care. 2005 [assessed Jan 2014]. Available from: http://www.gov.scot/Resource/Doc/1095/0001719.pdf.

89. NHS Scotland. Clinical Standards: Specialist palliative care. 2002 [assessed Jan 2014]. Available from: http://www.palliativecarescotland.org.uk/content/ publications/ClinicalStandardforSPC.pdf.

90. National Institute for Health and Care Excellence. Improving outcomes in gynaecological cancer: The Manual; 1999 [assessed Jan 2014].

91. Sachse M, Simon S. Palliative Medicine: Essays - Reports - Discussion Posts Comments: Liverpool Care Pathway Practical assistance. 2008 [assessed Sep 2013]. Available from: http://www.aerzteblatt.de/download/files/2009/05/ down137014.pdf.

92. Muszbek K. Practice and opportunities of the Hungarian hospice care provided at home. 2013 [assessed Nov 2011].

93. Van den Eynden B, Waerenburgh C, Streffer ML, Wens J. Palliative care pathway in General Practice. 2012 [assessed Jan 2014]. Available from: http://www.pro-spinoza.be/wp-content/uploads/2013/10/vs-19-december2011-Handboek-ZPPZ.pdf.

94. IKNL (Dutch Association of Comprehensive Cancer Centers). Integrated Oncological Pathways: prostate carcinoma; 2010 [assessed Jan 2014]. Available from: http://www.oncoline.nl/index.php?pagina=/richtlijn/item/ pagina.php\&richtlijn_id=575.
95. IKNL (Dutch Association of Comprehensive Cancer Centers). Integrated Oncological Pathways: colon-rectum carcinoma; 2010 [assessed Jan 2014]. Available from: http://www.google.com/url?sa=t\&rct=j\&q=\&esrc=s\&frm= $1 \&$ source $=$ web \&cd $=24 \&$ ved $=0 C D 4 Q F j A D O B Q \& u r l=h t t p \% 3 A \% 2 F \% 2 F w w w$. ikz.nl\%2Fuploaded\%2Fbibliotheek_upload_document\%2F3256\%2Fformat\% 2520colonrectumcarcinoom.pdf\&ei=iRJMUoycJoPUOQXqOlHQBA\&usg= AFQjCNENEZXI4eCOAZdJxLqB7chpjZrm-g.

96. MC Leeuwarden. Flow chart glioblastoma. 2012 [assessed Jan 2014]. Available from: http://www.mccleeuwarden.nl/Downloads/489/ 2012\%200CL\%20GBM.pdf.

97. Agustín Illueca MP, Arrieta Canales J, Benites Burgos A, del Rio García ML, Moral Lamela A, Rodrigez Franco E, Saldaña Martínez MJ, Vázquez Quiroga B, Vegas Ibañez, F. Manual for the management of patients in palliative care in outpatient ER. 2011 [assessed Nov 2013]. Available from: http://www. semesmadrid.es/docs-dues/Manualurgencias.pdf.

98. Rincón Carlavilla A, Molina Morate MA, Albert García P, Barrios Moreno A, Escós Quílez C, García Navalón P, Jarabo Crespo Y, Martínez de Dueñas E, Martínez Sanz MD, Lillo Tejeda MP, Muelas Herraiz F, De Miguel Ibáñez R, Abáigar Martínez de Salinas A, Díaz García JM, Ortega Fernández P, Saíz Santos S, Vellisca Ayllón M. Home care program in primary care; 2004 [assessed Nov 2013]. Available from: http://www.ingesa.msssi.gob.es/ estadEstudios/documPublica/pdf/atDomiciliaria.pdf.

99. Cía Ramos R, Fernández Lopez A, Boceta Osuna J, Duarte Rodríguez M, Camacho Pizarro T, Cabrera Iboleón J, Gómez Huelgas R, Gil Piñero E, Mateos Rodríguez J, Martín Roselló M, Mogollo Galván MA, Pérez Ramírez JL, Sanz Amores R, Vinuesa Acosta FJ. Integrated care process of Palliative Care. 2007 [assessed Nov 2013]. Available from: http://www.juntadeandalucia.es/ salud/export/sites/csalud/galerias/documentos/p_3_p_3_procesos_ asistenciales_integrados/cuidados_paliativos/cuidados_paliativos.pdf.

100. Naveira Gómez C, Olalla Gallo MA, Miquel Vázquez MP, Vara Hernando FJ, Arizcun Sánchez-Morate A, García Izquierdo J, Sánchez Domínguez F, Busto Pico MS, Rodríguez-Losada Allende M, Arranz Sanz JC, Igea Arisqueta F. Palliative care in the oncologic patient. Documents for integrated care processes related to cancer management. 2005 [assessed Nov 2013]. Available from: http://www.seecir.es/bibliograficos/material/Cuidados_ Paliativos.PDF.

101. Cardiff \& Vale NHS Trust. Care pathway for the last days of life; 2004 [assessed Sep 2013]. Available from: http://www.wales.nhs.uk/sites3/ documents/362/pathway\%20for\%20l\%E2\%80\%A6st\%20days\%20of\%20li.pdf.

102. National End of Life Care Programme. The route to success in end of life care: achieving quality for social work; 2012 [assessed Jan 2014]. Available from: http://www.nhsiq.nhs.uk/resource-search/publications/eolc-rts-social-work.aspx.

103. The Melanoma Task Force. Quality in melanoma care: a best practice pathway. 2012 [assessed Jan 2014]. Available from: http://www.bapras.org. uk/docs/default-source/commissioning-and-policy/melanoma-guidelinesseptember-2012.pdf?sfvrsn=0.

104. NHS Derbyshire County and NHS Derby City. Derbyshire End of Life Care Guidance: a pathway for supporting people in the last year of life; 2010 [assessed Jan 2014]. Available from: http://www.dchs.nhs.uk/assets/public/ dchs/dchs_about_us/End-Of-Life-Care/51636-End-of-Life-Care-16pp-final.pdf.

105. Prisma. Transparent reporting of systematic reviews and meta-analyses. 2015 [assessed Dec 2014]. Available from: http://www.prisma-statement.org/.

106. The Gold Standard Framework. http://www.goldstandardsframework.org.uk/ [accessed Oct, 2014]

107. Greene FL PD, Fleming ID, Fritz AG, Blavk CM, Haller DG, Morrow M, AJCC. Cancer Staging Handbook. 2002.

108. Hui D, Elsayem A, De La Cruz M, et al. Availability and integration of palliative care at US cancer centers. JAMA. 2010;303(11):1054-61.

109. Smith TJ, Temin S, Alesi ER, et al. American Society of Clinical Oncology provisional clinical opinion: the integration of palliative care into standard oncology care. J Clin Oncol. 2012;30(8):880-7.

110. Barton M. Early outpatient referral to palliative care services improves endof-life care. CA Cancer J Clin. 2014;64(4):223-4.

111. Howe M, Burkes R. Collaborative care in NSCLC; the role of early palliative care. Front Oncol. 2014;4:192.

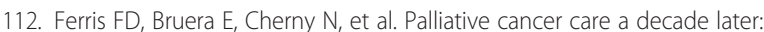
accomplishments, the need, next steps: from the American Society of Clinical Oncology. J Clin Oncol. 2009;27(18):3052-8.

113. Dalgaard KM, Bergenholtz $H$, Nielsen ME, Timm H. Early integration of palliative care in hospitals: a systematic review on methods, barriers, and outcome. Palliat Support Care. 2014;First View:1-19. 
114. Partridge A, Seah D, King T, Leighl NB, Hauke R, Wollins D Von Roenn JH. Developing a service model that integrates palliative care throughout cancer care: the time is now. J Clin Oncol. 2014;32 8 Sept [e-published ahead of print at www.jco.org].

115. Kendall M, Boyd K, Campbell C, Cormie P, Fife S, Thomas K, et al. How do people with cancer wish to be cared for in primary care? Serial discussion groups of patients and carers. Fam Pract. 2006;23(6):644-50.

116. Harding R, Selman L, Agupio G, Dinat N, Downing J, Gwyther L, et al. The prevalence and burden of symptoms amongst cancer patients attending palliative care in two african countries. Eur J Cancer. 2011;47(1):51-6.

117. Rowland K, Schumann S-A. PURLs. Palliative care: earlier is better. J Fam Pract. 2010;59:695-8.

118. Gaertner J, Wolf J, Frechen S, et al. Recommending early integration of palliative care-does it work? Support Care Cancer. 2012;20:507-13.

119. Yoong J, Park ER, Greer JA, et al. Early palliative care in advanced lung cancer: a qualitative study. JAMA Intern Med. 2013;173:283-90.

120. Bruera E, Hui D. Integrating supportive and palliative care in the trajectory of cancer: establishing goals and models of care. J Clin Oncol. 2010:28:4013-7.

121. Griffin JP, Koch KA, Nelson JE, Cooley ME. Palliative care consultation, quality-of-life measurements, and bereavement for end-of-life care in patients with lung cancer: ACCP evidence-based clinical practice guidelines (2nd edition). Chest. 2007;132(3):404S-22S

122. Greer JA, Jackson VA, Meiere DE, Temel JS. Early integration of palliative care services with standard oncology for patients with advanced cancer. CA Cancer J Clin. 2013;63:349-63.

123. Rabow MW, Hardie GE, Fair JM, McPhee SJ. End-of-life care content in 50 textbooks from multiple specialties. JAMA. 2000;283(6):771-8.

\section{Submit your next manuscript to BioMed Central and we will help you at every step:}

- We accept pre-submission inquiries

- Our selector tool helps you to find the most relevant journal

- We provide round the clock customer support

- Convenient online submission

- Thorough peer review

- Inclusion in PubMed and all major indexing services

- Maximum visibility for your research

Submit your manuscript at www.biomedcentral.com/submit

) Biomed Central 